\title{
Effect of Corporate Tax Aggressiveness on Firm Growth in Nigeria: An Empirical Analysis
}

Ifurueze, Meshack S.

Faculty of management sciences,

Department of Accountancy,

Chukwuemeka Odumegwu

Ojukwu University,

Igbariam, Nigeria
John-Akamelu, Racheal C.

Faculty of management sciences,

Department of Entrepreneur

Studies Unit,

Nnamdi Azikiwe University,

Awka, Nigeria
Iyidiobi, Felicia C.

Faculty of management sciences,

Department of Accountancy,

Enugu State University of Science

and Technology,

Enugu, Nigeria

\section{ABSTRACT}

The main objective of this study is to investigate the effect of corporate tax aggressiveness strategies on firm growth in Nigeria. The specific objectives were to; investigate the effect of $\odot$ leverage tax aggressiveness strategy on firm growth in Nigeria and evaluate the effect of effective tax rate aggressiveness strategy on firm growth in Nigeria. Ex post Facto research design was adopted and the data were collected from annual reports and accounts of Nigerian food production companies. Pooled multiple regression analysis was employed to test the formulated hypotheses. The study found that Leverage (LEV) to impact positively on our dependent variable, Firm Growth. This impact was not statistically significant. The study found that Effective tax rate (ETR) to impact positive on our dependent variable, Firm Growth, but this impact was statistically significant. Since the influence of effective tax rate is not statistically significant and so, should be ignored as a determinant of firm growth in Nigeria. Therefore on the basis of efficient use of tax rate to generate growth should be encouraged.

\section{KEY WORDS: Corporate tax aggressiveness,} leverage tax, effective tax rate and firm growth

\section{INTRODUCTION}

The concept of taxation is as old as mankind. It has been an effective way of getting money from people and institution to effectively run a society, at the same time; it can be seen as a great way to take value and income away from the people. It has been opined by Leory and Babra (2008) that tax benefits cannot be estranged from the tax system and that the benefit cannot be separated away from equilibrium concern and eventual business evaluation. However, the modern tax as defined by Omotoso (2001) is the compulsory charge imposed by a public authority on the income of individuals and income of companies as stipulated by the government decrees, acts or laws irrespective of the exact amount of services rendered to the payer in return. Tax administration on the other hand can be described as the process of assessing and collecting taxes from individuals and companies by relevant tax authorities in such a way that the correct amount is collected efficiently and effectively with minimum tax avoidance or evasion.

The degree of tax aggressiveness will depend on the characteristics of the owners of family firms and the managers of non-family firms with respect to the costs and benefits of corporate tax planning policies. However, the relationship between the characteristic of being a family firm and tax aggressiveness cannot be clearly identified. Due to the greater block holdings and longer investment horizons, the owners of family firms need to be more concerned with the potential penalties and the reduction of the share price that can be caused by overly aggressive tax planning (Antonio \& Giliard , 2014).

Tax has been a crucial topic of discussion in the literature. However, it focused more on economic side than corporate side (Oboh, Yeye \& Isa, 2003; Ifeuko 2008).Bulk of these studies has been looking at the macro aspect of taxation with very little concentration on the micro or corporate aspect of taxation. This is one area the study is going to be more specific as it 
tries to look to tax more precisely from the corporate or micro aspect.

The studies have empirically tested the relationship with inconclusive results. While some found improvement in the accounting information quality of some countries that adopted international accounting standards which then helps to reduce tax aggressiveness? Such studies include: Hanlon and Slemrod (2009): Chenhall and Carla,(2010),Chun, Hamid and Daniel (2012) While others like: Kao and Wei, (2014) ,Lise and Roberto (2015) think otherwise. Some researchers such as Leuz (2003) further argue that, managers and controlling owners have the ability to manage taxes in order to mask true firm performance and to conceal their private control benefits from outsiders.

In addition, most of these prior studies were carried out in foreign countries in relation to the changes in international financial reporting standard, this however create gap in which this study set up to fill, hence to domesticate the study in Nigerian corporate firms.

The main objective of this study is to investigate the effect of corporate tax aggressiveness strategies on firm growth in Nigeria. The specific objectives were to:

1. Investigate the effect of leverage tax aggressiveness strategy on firm growth in Nigeria.

2. Evaluate the effect of effective tax rate aggressiveness strategy on firm growth in Nigeria.

\section{REVIEW OF RELATED LITERATURE Conceptual Framework}

\section{Tax Aggressiveness}

However, more of these works have been in developed countries and the effect of accounting reporting system has become very important as different recording systems can give rise to loopholes that can help company managers to aggressively hide tax away from both the state and the shareholders.

Mills and News berry (2001) suggests that managers have a more direct access to financial reporting than to tax reporting, influencing accounting income rather than tax income. Consequently, deferred taxation can be increased or decreased according to management earnings targets and how aggressive they choose to go about it.
Every company that wants to operate more profitably must equip herself with external source of funding .This mostly and primarily comes from leverage more than equity, since leverage is preferred to equity due to the less complex and expensive process of getting it. It can also be noted that most of the time, corporation tax rates influences debt financing since debt interest payments are typically tax deductible, whereas dividend payments are not, as pointed out by (Beke,2011).

It is, therefore, logical to believe that companies can use debt induced strategies like debt inflation to increase their tax reductions more aggressively than companies that doesn't have such debt, Joe-veer, (2013), This, then suggests that a company with interest tax advantage could increase or reduce its debt profile in a way that it gives them some sort of huge tax advantage. Tax aggressiveness can be proxy by leverage, effective tax rate, book tax value, market value and firm size.

\section{Leverage}

Leverage is the result of using borrowed capital as a source of funding when investing to expand the firm's asset base and generate returns on risk capital. Leverage is an investment strategy of using borrowed money: specifically, the use of various financial instruments or borrowed capital to increase the potential return of an investment. Leverage can also refer to the amount of debt used to finance assets. When one refers to something (a company, a property or an investment) as "highly leveraged," it means that, the item has more debt than equity (Towery, 2012).

In finance, leverage (sometimes referred to, as gearing in the United Kingdom and Australia) is any technique involving the use of borrowed funds in the purchase of an asset, with the expectation that the after tax income from the asset and asset price appreciation will exceed the borrowing cost. Normally, the finance provider would set a limit on how much risk, he is prepared to take and will set a limit on how much leverage it will permit, and would require the acquired asset to be provided as collateral security for the loan. For example, for a residential property, the finance provider may lend up to, say, $80 \%$ of the property's market value, for a commercial property it may be up to $70 \%$, while on shares it may lend up to, say, $60 \%$ or none at all, on some shares. 
Leveraging enables gains and losses to be multiplied. On the other hand, there is a risk that leveraging will result in a loss - i.e., when actually it turns out that financing costs exceed the income from the asset, or because the value of the asset has fallen.

While leverage magnifies profits when the returns from the asset is more to offset the costs of borrowing, leverage may also magnify losses. A corporation that borrows too much money might face bankruptcy or default during a business downturn, while a less-leveraged corporation might survive. An investor who buys a stock on $50 \%$ margin will lose $40 \%$ if the stock declines $20 \%$ (Leory \& Babra, 2008).

This may happen exactly when there is little market liquidity and sales by others at depressing prices. It means that as things get bad, leverage goes up, multiplying losses as things continue to go down. This can lead to rapid ruin, even if the underlying asset value decline is mild or temporary. Leory and Babra (2008) noted that the risk can be mitigated by negotiating the terms of leverage, by maintaining unused room for additional borrowing, and by leveraging only liquid assets (Heitzman \& Michelle, 2010).

On the other hand, the extreme level of leverage affordable in forex trading presents relatively low risk per unit due to its relative stability when compared with other markets. Compared with other trading markets, forex traders must trade at much higher volume of units in order to make any considerable profit. For example, many brokers offer 100:1 leverage for investors, meaning that someone bringing $\$ 1,000$ can control $\$ 100,000$ while taking responsibility for any losses or gains their investments incur. This intense level of leverage presents equal parts to risk and reward.

There is an implicit assumption in that account, such that the underlying levered asset is the same as the unlevered one. If a company borrows money to modernize, or add to its product line, or expand internationally, the additional diversification might be more to offset the additional risk from leverage (Leory \& Babra, 2008). Or if an investor uses a fraction of his or her portfolio to manage stock index futures and puts the rest in a money market fund, he or she might have the same volatility and expected return as an investor in an unlevered equity index fund, with a limited downside Heitzman, (2010). Or if both long and short positions are held by a pairtrading stock strategy, the matching and off-setting economic leverage may lower overall risk level.

So when adding leverage to a given asset always adds risk, it is not also the case that a levered company or investment is always riskier than an unlevered one. In fact, many highly levered hedge funds have less return volatility than unlevered bond funds, and public utilities with lots of debt are usually less risky stocks than unlevered technology companies (Leory \& Babra 2008).

Effective Tax Rate: The effective tax rate is the average taxation rate for a corporation or individual. The effective tax rate for individuals is the average rate at which their earned income is taxed, and the effective tax rate for a corporation is the average rate at which its pre-tax profits are taxed.(Jon 2012).

The effective tax rate is the average rate at which an individual is taxed on earned income, or the average rate at which a corporation is taxed on pre-tax profits

It is important to note that the amount of tax payments in cash that an individual or corporation actually pays out may differ materially from the amount of tax expense in a given period. This is because most companies prepare two different sets of financial statements: one for reporting purposes and one for tax purposes.

\section{Economic Growth}

Economic growth is the increase in the inflationadjusted market value of the goods and services produced by an economy over time. It is conventionally measured as the percent rate of increase in real gross domestic product, or real GDP, usually in per capita terms.

Growth is usually calculated in real terms - i.e., inflation-adjusted terms - to eliminate the distorting effect of inflation on the price of goods produced. Measurement of economic growth uses national income accounting. Since economic growth is measured as the annual percent change of gross domestic product (GDP), it has all the advantages and drawbacks of that measure. The "rate of economic growth" refers to the geometric annual rate of growth in GDP between the first and the last year over a period of time. Implicitly, this growth rate is the trend in the average level of GDP over the period, which 
implicitly ignores the fluctuations in the GDP around this trend.

An increase in economic growth caused by more efficient use of inputs (such as labor productivity, physical capital, energy or materials) is referred to as intensive growth. GDP growth caused only by increases in the amount of inputs available for use (increased population, new territory) is called extensive growth (Wikipedia, 2017).

Three waves of interest have currently emerged in studying economic growth. The first wave is associated with the work of Harrods (1900-1978) and Domar (1914-1997) in what was termed the "Harrods - Domar Model". The theory presupposed that growth depended on a country's savings rate, capital/output ratio, and capital depreciation. This theory has been criticized for three reasons. Firstly, it centers on the assumption of exogeneity for all key parameters. Secondly, it ignores technical change, and lastly, it does not allow for diminishing returns when one factor expands relative to another (Essien, 2002).

The second began with the neoclassical (Solow) model, which contained the thinking that growth reflected technical progress and key inputs, (labour and capital). It allowed for diminishing returns, perfect competition but not externalities. In the neoclassical growth process, savings were needed to increase capital stock, capital accumulation had limits to ensure diminishing marginal returns, and capital per unit of labour was limited. It postulates that growth also depended on population growth rate and that growth rate amongst countries was supposed to converge to a steady state in the long-run. Despite the modifications, the basic problems associated with the neoclassical thinking are that it hardly explains the sources of technical change (Essien \& Bawa, 2007).

\section{Empirical Review}

Lots of research has been conducted to assess the extent tax aggressiveness affect firm growth. Dhaliwal, Gleason, and Mills (2004) investigated whether income tax expense is regularly used to achieve earnings targets and concluded that aggressive tax expense provides a final opportunity to meet earnings targets after the firm has agreed to any pre-tax adjusting entries required by the independent auditors.
Similarly, Desai and Dharmapala (2006) supported this argument. It is believe that the reporting quality alone cannot provide sufficient support that will help reduce tax aggressiveness of companies. Chen, Chen, Chen et al. (2010) study the relationship between tax aggressiveness and agency conflicts present in family firms and non-family firms. The reason to deal with these two types of companies separately is that, according to the authors, the presence of members of the founding family in the ownership structure implies a greater potential for conflict between majority and minority shareholders and a lesser one between owners and managers in comparison to non-family firms. This difference can impact the costs and benefits of implementing more or less aggressive tax policies.

Donohue (2011) examined why derivatives are appealing for tax avoidance, how they reduce explicit taxes, and which firms use them to avoid taxes. Using multiple regression analysis, he finds that derivatives are useful for avoiding taxes because they enable the replication of economic positions, which blurs economic substance and industrial ambiguity in tax reporting, also tax aggressiveness derivatives users have several commonalties which includes foreign operators, more capital assets, and the use of auditorprovided tax security and industry-specialist auditors.

Towery (2012) examined the effect of mandatory disclosures of tax aggressiveness to tax authorities on firms' reporting decisions. Schedule UTP requires firms to disclose federal income tax positions to the Internal Revenue Service that have been classified as 'uncertain' for financial reporting purposes. In showing how Schedule UTP disclosure requirements affect private and public reporting decisions, the study provide insights into the usefulness of these disclosures. Using confidential tax return data and public financial statement data, the study find that after imposition of Schedule UTP reporting requirements, firms report lower financial reporting reserves for uncertain income tax positions, but do not claim fewer income tax benefits on their federal tax returns. These findings suggest that some firms changed their financial reporting for uncertain tax positions to avoid Schedule UTP reporting requirements without changing the underlying positions.

Jon (2012) provided evidence on a significant real consequence of an opaque financial reporting 
information environment: increased corporate tax aggressiveness. Using an inter- national sample of firms, the study find that firms with a more opaque information environment, as measured at both the firm and country level, exhibit higher levels of firmspecific tax avoidance. Similarly, the results from tests using the initial enforcement of insider trading laws provide additional support for a directional hypothesis. In support of the firm-level findings, also find evidence in the aggregate that opacity is associated with countries collecting less corporate tax revenues as a percentage of gross domestic products.

Blaufus and Zinowsky (2013) analyzed how the Big Five personality traits and professional experience affect the aggressiveness of tax preparers' recommendations. To this aim, they conduct a survey among tax professionals of a Big Four accounting firms. Using treatment-effects regressions, the study find that personality traits have direct and indirect effects on tax aggressiveness. Personality traits affect the decision to remain in the organizational environment of the Big Four accounting firm, and the experience in this firm is significantly related to tax aggressiveness. Their data suggest that enhancing work experience at the accounting firm leads to lower tax aggressiveness and that the organizational culture appears to be an important determinant of tax aggressiveness. Moreover, they provide evidence that the danger of potential reputation losses reduces subjects to tax aggressiveness regardless of whether the subject is highly experienced or not.

Fuest, Spengel, Finke, et al (2013) discussed the issue of profit shifting and "aggressive" tax planning by multinational firms. The paper makes two contributions. First, it provides some background information to the debate by giving a brief overview of existing empirical studies on profit shifting and by describing arrangements for IP-based profit shifting which are used by the companies currently accused of avoiding taxes. The study shows that preventing this type of tax avoidance is, in principle, straightforward. Second, they argue that, in the short term, policy makers should focus on extending withholding taxes in an internationally coordinated way.

Guenther, Matsunaga and Williams (2013) distinguished between the concepts of tax avoidance, tax aggressiveness, and tax risk and examine which, if any, of those concepts is related to overall firm risk. Prior research has argued that aggressive corporate tax avoidance, as measured by low cash effective tax rates or high reserves for unrecognized tax benefits, increases firm risk, thereby requiring firms to provide risk-taking incentives to managers. They found a significantly positive relationship between tax risk and firm risk, but do not find evidence of a significant association between either tax avoidance or tax aggressiveness and firm risk.

Razak and Adafula (2013) examined the influence of attitudes of individual taxpayers on tax compliance decisions. Descriptive and inferential statistics were applied to analyze survey responses and firm questionnaires administered to operators of SMEs in Tamahe. They found that individuals are highly concerned with the amount of taxes they pay. Again, it was revealed that, the level of governmental accountability and transparency did not significantly impact taxpayer's attitudes.

Fukofuka (2013) examined the prediction of tax evasion and their usefulness for identifying tax evasion. Through presentation of contextual framework of corporate income tax evasion, structured with twelve ideas and twenty-five dynamic with sample game theory model. They found that in order to promote the tax audit cut-off policy that incorporates reward programme for agent of government, you must ensure that audit frequency and tasks independence of the agent of government are put in place.

Chyz, Gaertner, Kausar et al (2014) investigated whether firms with overconfident CEOs pursue more aggressive tax positions and yet assign high expectations of their final reliability, even if these positions were to be audited by a relevant taxing authority. In their empirical tests they first document positive associations between proxies for the aggressiveness of firms' tax positions and overconfidence. They then test for associations between overconfidence and the financial reporting of uncertain tax benefits under FIN 48. Prior tax aggressiveness research leads to the expectation of a similarly positive association with uncertain tax benefits. Instead, the study found that the same group of firms with overconfident CEOs report lowers uncertain tax benefits in the financial statements.

Saratu (2015) examined the impact of competition on tax avoidance activities among Nigerian Deposit Money Banks. The study used panel regression model 
to analyze the data obtained from the financial statements of 15 banks operating on the Nigerian Stock Exchange for a period of 10 years. The result of the random effect revealed that competition has a positive and an insignificant impact on tax avoidance.

Watson (2015) investigated the influence of pre-tax earnings performance on the relationship between corporate social responsibility (CSR) and tax avoidance. Using slack resource theory of Penrose1959, he found that the relationship between CSR and tax avoidance in firms is moderated by earnings performance.

Aumeenon, Jufurnath and Soondrun (2016) measured the impact of the tax evasion on the Gross Domestic Product (GDP) per-capita of Sub- Saharan Africa. The relationship between the GDP per capita and tax evasion is tested using the generalized least squared. They found that there is a positive impact of tax evasion on GDP per capita.

Kourdoumpalou (2016) examined the association between corporate governance practices and the extent of tax evasion for the Greek. Using multiple regression analysis, the researcher found that tax evasion is lower when the chairman of board is also the owner of the company and also that tax evasion is higher when board members are also employees of the company.

Abubakar (2017) examined why taxes in Harari were multifaceted. Using literatures and accounts written by different historians and various tax related documents. It was found that taxes from Islamic view point and manifestation of civilization in Harari were responsible for taxes in Harari being multifaceted.

Babatunde, Ibukun and Oyeyemi (2017) examined the impact of taxation on economic growth in Africa from 2004-2013.Descriptive statistics and stationary tests using Augmented Dickey Fuslew (ADF) test, Leven et al model and Shin Stat test. The study indicated that tax revenue is positively related to GDP and promote economic growth in Africa.

Chen and Lin (2017) investigate the effect of information asymmetry on corporate tax avoidance, using a difference-in- differences matching estimator to assess the effects of changes in analyst coverage caused by broker closures and mergers. They found that firms avoid tax more aggressively after a reduction in analyst coverage, also that the effect is normally driven by firms with higher existing taxplanning capacity eg. Smaller initial average and smaller number of peer firms. The effect is more prevalent in industries where reputation matters more and in firms subject to less monitoring from tax authorities.

Koutoupis, Drogalas and Pazarskus (2017) examined the merger effects on the accounting performance of Greek firms in parallel with their taxation impact, during the period of economic crisis in Greece. The study analyses twelve (12) accounting measures from financial statements and financial ratios of a sample of Greek listed firms in Athens Exchange from 20102015. The study found that there is evidence that there is some effect from the new GITC and it provides function opportunities for capital gains, not subject to tax from mergers, during the period of the economic crisis in Greece.

Lisa De, Jordan and Jeri (2017) Assessed whether common empirical tests reliably identify tax avoidance. In order to determine the tax avoidance largely depends on results generated using such tests. They address this question by using a controlled environment to examine the effectiveness of empirical tests that use effective tax rates (ETR) and book-tax differences (BTD) as tax avoidance proxies. They used Comp -stat data with three tax avoidance strategies and examine how reliably empirical tests identify this incremental simulated tax avoidance, all things being equal. They found that power varies with the proxy and the type of tax avoidance.

Khan, Srinivasan and Tan (2017) examined new evidence on the agency theory of corporate tax aggressiveness, using the Russell index reconstitution setting to isolate exogenous stocks to institutional ownership and regression discontinuity design that facilitates sharper identification of treatment effects. They found that significant and discontinuous increase in tax avoidance following Russell 2000, increase ownership concentration in tax avoidance.

Vythelinqum, Soondram \& Jugurnath (2017) assessed the level of tax and identified factors that shape tax morale in Mauritius, using a self-developed questionnaire was distributed to 250 randomly respondents and a logistic regression analysis was used to analyze the data collected. The study found that Socio-demographic and Socio-economic factors 
have an impact on tax morale and it can be seen that social norms, fairness and equity, trust in government and in tax authority are determinants that shape tax morale.

Wegener and Labelle (2017) examined the relationship between business ethics and tax aggressiveness. Building on the conceptual model of corporate moral development, they hypothesize and found a negative association between the level of business ethics and tax aggressiveness. For our sample of U.S. firms, companies with a higher level of business ethics are less likely to be tax aggressive. Our results are robust to the use of two proxies for tax aggressiveness: the 'mainstream' effective-tax-rate measure and the unrecognized tax benefit, which have been identified as capturing them least and the most aggressive tax positions respectively. While they support their business ethics prediction in both their models, they also found a positive relationship between the quality of corporate governance (measured without ethical characteristics generally associated with good corporate governance) and tax aggressiveness. Their interpretation of these results is that, while ethical firms are concerned about paying their fair share of taxes, shareholders' interest still comes first.

Abdul and Wang'ombe (2018) examined the influences of measures of tax compliance costs on tax compliance behavior among medium and large taxpayers in Kenya. Using the structural equation modeling (SEM) technique to establish the key cost drivers built through survey data of $40 \%$ variations in tax compliance behavior. The study found that tax compliance in Kenya significantly declines with increase in tax compliance costs.

Oduro, Asiedu and Tackie (2018) investigated the factors that determine whether a tax payer would evade tax or not. A cross-sectional survey, using structural equation and modeling with bootstrapping analysis and data from a sample of 1,052 tax payers was analyzed. It was found that traditional factors and institutional factors positively influenced tax evasion.

It is believed that the reporting quality alone cannot provide sufficient support that will help reduce tax aggressiveness of companies. Intention to manage taxes aggressively is driven by some underlying motives such as window dressing of financial reports prior to public offering, to meet bonus targets in order to increase regulatory benefits.

Dhaliwa, Gleason and Mills (2004) found that aggressive tax expense provides a final opportunity to meet earnings target. Desai and Dharmapala (2006) supported the argument of Dhaliwa, Gleason and Mills (2004) they stated that reporting quality alone cannot provide sufficient support that will help reduce tax aggressiveness of companies. Chen et al (2010) found evidence that aggressiveness and agency conflicts present in family firms and non-family firms can impact that costs and benefits of implementing more or less aggressive tax policies.

Lanis and Richardson (2013) showed that is a positive and statistically significant association between corporate tax aggressiveness and CSR disclosure. Antonio and Giliard (2014) opined that there is a significant relationship between classification as a family firm and tax aggressiveness.

Harvey (2014) found that the degree of corporate tax aggressiveness can ebb and flow depending upon the legal environment. Lee, Alfreda and Minton (2015) agreed that tax shelters and uncertain tax benefits can be used as proxies for aggressive tax avoidance. Watson (2015) and Amidu, Kwakye, Harvey and Yorke (2016) found that the relationship between CSR and tax avoidance in firms is moderated by earnings performance. Chen and Lin (2017) found that firms avoid tax more aggressively after a reduction in analyst coverage. Mgbame, ChijiokeMgbame and Yekini (2017) found that there is a negative relationship between CSR performance, firm size and tax aggressiveness in Nigeria. Khan, Srinivasan and Tan (2017) agreed that there is a significant and discontinuous increase in tax avoidance following Russell 2000, increase ownership concentration in tax avoidance. Jeongho and Chaechang (2017) believed that tax authorities can regulate firms that engaged in tax avoidance and encourage firms to conduct CSR activities. Wegner and Labelle (2017) found a negative association between the level of business ethics and tax aggressiveness. Oduro, Asiedu and Tackie (2018) established that traditional factors and institutional factors positively influenced tax evasion.

From the above review, it is obvious that most of these empirical studies were conducted in developed 
countries, with only one or two study(s) in developing nations like Nigeria.

\section{METHODOLOGY}

\section{Research Design}

Due to the nature of this study, Ex-Post facto research design will be adopted. This is appropriate because the study aims at measuring the relationship between one variable and another in which the variables are not manipulated.

\section{Population of the Study}

This study makes use of seven manufacturing companies that are under foods product in Nigeria. The study covered ten years annual reports and accounts of these companies from 2007 to 2016. The name of these companies under foods production in Nigerian manufacturing companies are:

1. Big treat Nigerian plc,

2. Dangote Four Nigerian Plc,

3. Dangote Sugar Nigerian Plc,

4. Honeywell Flour mill Nigerian plc,

5. Nestle Nigerian Plc,

6. Cadbury Nigerian Plc,

7. UAC Nigerian plc.

In chosen the sample size, the researcher used Stratified Random Sampling to select six foods production in Nigeria for the sample size of the study. This company (Big treat Nigerian Plc.) were not selected for lack of availability of annual reports and audited accounts.

\section{Method of Data Analysis}

To achieve the objectives of this study, the data required were those of the discriminating variables that include: effective tax rate and book-tax difference. Hypotheses formulated for the study were tested with the pooled multiple regression using Eview 9.0 software package.

\section{Decision rule:}

Using SPSS, 5\% is considered a normal significance level. The accept reject criterion was based on the pvalue, alternative hypothesis will be accepted.

\section{Model specification}

The predicted probability the firm is engaged in tax sheltering, computed as follows:

FMGRTH $=\beta_{1}$ LEVit $+\beta_{2}$ ETRit $\ldots \ldots \ldots \ldots \ldots \ldots$.et

FMGRTH $=\beta_{1}$ LEVit $\ldots \ldots \ldots \ldots \ldots \ldots \ldots \ldots \ldots . .$. et

FMGRTH $=\beta_{2}$ ETRit .......................et

Where:

FMGRTH $=$ Firm Growth

LEVit $=$ Long term debt $(D L T T)$ scaled by total assets $(A T)$ in year $t$;

ETR - effective tax rate $=$ Total income tax expense / earnings before income tax

\section{Data analysis}

Table 1: Descriptive statistics of the sampled companies

\begin{tabular}{|c|c|c|c|c|c|}
\hline Variables & Mean & Max & Min & Std. Dev & JB (P-value) \\
\hline FMGRTH & 5531891 & 2223564 & -9113036 & 7432987 & $1.36(0.51)^{*}$ \\
\hline LEV & 0.492625 & 0.777000 & 0.038000 & 0.203860 & $6.2625(0.04)^{*}$ \\
\hline ETR & 0.243450 & 1.328000 & -0.636000 & -0.636000 & $107.80(0.00)^{*}$ \\
\hline
\end{tabular}

Source: Researcher's computation (2018)

Note: $1 \%$ level of significance

Table 1 shows the mean (average) for each of the variables, their maximum values, minimum values, standard deviation and Jarque-Bera (JB) Statistics (normality test). The results in table 1 provided some insight into the nature of the selected Nigerian quoted companies that were used in this study.

Firstly, it was observed that on the average over the ten (10) years periods (2007-2016), the sampled quoted companies in Nigeria were characterized by positive Firm Growth (PAT =5531891). However, it was observed that during the period under study, that the effective tax rate was approximately $24 \%$. Moreover, in table 1, the Jarque-Bera (JB) which test for normality or the existence of outliers or extreme values among the variables, shows that most of the variables are normally distributed at $1 \%$ level of significance except Leverage (LEV) is distributed at $5 \%$. This means that any variables with outlier are not likely to distort our conclusion and are therefore reliable for drawing generalization. This also implies that the least square estimate can be used to estimate the pooled regression model. 


\section{Correlation Analysis}

In examining the association among the variables, we employed the Pearson correlation coefficient (correlation matrix) and the results are presented in table 2

Table 2: Correlation Analysis Matrix

\begin{tabular}{|c|c|c|c|}
\hline & FMGRTH & LEV & ETR \\
\hline FMGRTH & 1.00 & 0.21 & 0.47 \\
\hline LEV & 0.21 & 1.00 & 0.12 \\
\hline ETR & 0.05 & 0.12 & 1.00 \\
\hline
\end{tabular}

Source: researcher's computation (2018)

The use of correlation matrix in most regression analysis is to check for multi-co linearity and to explore the association between each explanatory variable (LEV and ETR) and the dependent variable (FMGRTH) proxy as Profit after tax (PAT). Table 2 focused on the correlation between Firm Growth measured as FMGRTH and the independent variables (LEV and ETR).

Finding from the correlation matrix table shows that all our independent variable, $(\mathrm{LEV}=0.05)$ were observed to be positively and weakly associated with Firm Growth. In checking for multi-colinearity, we notice that no teo explanatory variables were perfectly correlated. This means that there is no problem of multi-colinearity between the explanatory variables. Multi-colinearity may result to wrong signs or implausible magnitudes in the estimated model coefficients, and the bias of the standard errors of the coefficients.

\section{Testing of Hypotheses formulated}

In other to examine the impact relationships between the dependent variable FMGRTH and the independent variables (LEV and ETR) and to also test our formulated hypotheses, we used a pooled multiple regression analysis since the data had both time series (2007-2016) and cross sectional properties (8 quoted companies). The pooled interaction based multiple regression results are presented and discussed in Table 3 below.
Table 3: FMGRTH Pooled Regression Results Variables t-statistics Prob
$\mathrm{C}$
$-0.372199$
0.71
LEV
0.997048
0.33
ETR
0.343832
0.73

R-squared 0.63

$\begin{array}{ll}\text { Adjusted R-squared 0.59 } & \text { Akika Info Criterion } 33.72 \\ \text { F-Statistics 14.75521 } & \text { Schwarz Criterion 33.93 } \\ \text { Prob (F-Statistics) 0.00 } & \text { Durbin-Watson stat } 1.86\end{array}$

Source: Researcher's computation through E-view 9.0 statistical package

In Table 3, R-squared and adjusted Squared values were (0.63) and (0.59) respectively. The indicates that all the independent variables jointly explain about $63 \%$ of the systematic variations in Firm Growth (FMGRTH) of our samples companies over the eight years periods (2007-2016). The F-statistics (14.76) and its P-value (0.00) show that the FMGRTH regression model is well specified.

Test of Autocorrelation: using Durbin-Waston (DW) statistics which we obtained from our regression result in table 4.3 , it is observed that DW statistics is 1.86 and an Akika Info Criterion and Schwarz Criterion which are 33.72 and 33.93 respectively also further confirms that our model is well specified. In addition to the above, the specific findings from each explanatory variable are provided as follows:

Leverage Tax Aggressiveness (LEV), based on the tvalue of 0.997048 and $p$-value of 0.33 , was found to have a positive influence on our sampled quoted companies Firm Growth and this influence is not statistically significant as its p-value is more than 0.10 value. This result, therefore suggests that we should accept our null hypothesis one ( $\left.\mathrm{Ho}_{1}\right)$ which states that the leverage tax aggressiveness strategies has no significant effect on firm growth in Nigeria. This means that on the basis of effective use of leverage to generate firm growth, firms with high leverage value performs better as the analysis reveals that for every \#1 increase in leverage value of firms in Nigeria, will lead to about \#1.00 decrease on Firm growth rate. However, this result is not statistically significant and therefore should not be used for any policy consideration. 
Effective tax rate aggressiveness (ETR), based on the $t$-value of 0.343832 and $p$-value of 0.73 was found to have a positive influence on our sampled quoted company's firm growth and this influence was not statistically significant since its p-value was more than $10 \%$. This result therefore suggests that we should reject our null hypothesis two $\left(\mathrm{Ho}_{2}\right)$ which states that effective tax rate aggressiveness strategies have no significant effect on firm growth in Nigeria. This means that effective tax rate impact positively on firm growth. However, this influence is not statistically significant and so, should be ignored as a determinant of firm growth in Nigeria. Therefore on the basis of efficient use of tax rate to generate growth, those firms with high effective tax rate perform better.

\section{Discussion of Findings}

Leverage tax aggressiveness (LEV) based on findings, was found to impact positively on our dependent variable, Firm Growth. This impact was not statistically significant. This finding therefore supports our aprori expectation and the findings of Clive, Petro and Jeffres (2013) and negates the view of Akanksha and Costanza (2016).

Effective tax rate (ETR) based on findings, was found to impact positive on our dependent variable, Firm Growth, but this impact was statistically significant. This finding therefore supports the finding of Clive, Petro and Jeffres (2013) and negates our aprori expectation and the view of Antonio and Giliord (2014).

\section{Conclusion and Recommendation}

In order to maximize the value of the firm, shareholders would like to minimize corporate tax payments net of the private costs of doing so; in other words they want the company to be optimally aggressive. There has been little rigorous empirical analysis of the benefits and costs to corporations of being tax aggressive. In this study, we attempt to fill this void, at least in part, by investigating the market reaction to an initial press mention that a firm was involved in a corporate tax shelter. The study found that leverage (LEV) impact positively on Firm Growth. This impact was not statistically significant. However, the study found that Effective tax rate (ETR) impact positive on Firm Growth, but this impact was statistically significant.
This means that on the basis of effective use of leverage and market value to generate firm growth, firms with high leverage value performs better as the analysis reveals that for every \#1 increase in leverage value of firms in Nigeria, will lead to about \#1.00 and \#0.32 decrease respectively on Firm growth rate. Meanwhile, with different IFRS implementation and convergence process between one country to another lead to different response of taxation issue. Based on the findings of the study, the researcher recommends that since the influence of effective tax rate is not statistically significant and so, should be ignored as a determinant of firm growth in Nigeria. Therefore on the basis of efficient use of tax rate to generate growth should be encouraged.

\section{References}

1. Abdul F. \& Wang'ombe (2018). Tax cost and tax compliance behavior in Kenya. Journal of Accounting and Taxation. https://doi.org/10.5897/JAT. 0283. Vol.10 (1) pp1-18.2018.

2. Abubakar, A. (2017). Taxes, Tax Payers and Collectors-Pre- and Post Menelik: Harari Experience. Jpurnal of Accounting and Taxation. https://doi.org/10.5897/ JAT 0212. Vol.9 (3). Pp.23-35.2017.

3. Aumeerun, B, Jugurnath, B \& Soondrum, H (2016). Tax Evasion: Empirical Evidence from Sub- Saharan Africa. Journal of Accounting and Taxation. https://doi.org/10.5897/JAT.0225. 8 (7) .pp.70-80.

4. Antonio, L. M. \& Giliard C. R. (2014).Family Firms and Tax Aggressiveness in Brazil. International Business Research; 7(3).

5. Babatunde, O. A, Ibukun, A.O \& Oyeyemi, O.G (2017). Taxation Revenue and Economic Growth in Africa. Journal of Accounting and Taxation. https://doi.org/0.5897/JAT .0236. vol.10 (6).

6. Beke, J (2011).International Business Accounting Standardization and Hungarian Practice. An International Business Research. www.ecsenet.org/ibr vol.4 No.1 (2011) pp125131, published by Canadian Center of Science and Education.

7. Blaufus, K\& Zinowsky, T (2013). Tax Professionals Tax Aggressiveness: Experimental Evidence on the Impact of Personality Traits, Preparer Penalties and Market 
International Journal of Trend in Scientific Research and Development (IJTSRD) ISSN: 2456-6470

Regulation.https;//www.stevern.uni.harmover.de/f ileadmin/steuern/team/mitorbeiten/Diss.zinowky

8. Chen, S., Chen, X., Cheng, Q., \& Shevlin, T. (2010). Are family firms more tax aggressive than non-family firms? Journal of Financial Economics, 95, 41-61. http://dx.doi.org/10.1016/j.jfineco.2009.02.003.

9. Chen, T \& Lin, C (2017). Does Information Asymmetry Affect Corporate Tax Aggressiveness? Journal of Financial and Quantitative Analysis. https//www.cambridge.org/core/journals/journalof-financial- and -quantitative-analysis.

10. Chenhall, R. K \& Carla, L.W (2010). A Review of I T Governance: A Taxonomy of Accounting Information Systems. Journal of Information System. Vol.24. issue 2 (fall 2010). https;//doi.org/10.2308/JIS.2010.24.2.107

11. Chun, P., Hamid, P \& Daniel, S (2012). Management of Accounting Information Systems: A case of a developing Country: Vietnam. Journal of Accounting \& \& Economics. https;//doi.org/10.1080/1608/625.202. 19(1)

12. Chyz, J. A., Gaertner, F., Kausar, A. \& Watson, L (2014). Overconfidence and Aggressive Corporate Tax Policy. JEL classification: D80, M40, H25.

13. Desai, M \& Dharmapala, D (2009). Corporate Tax Avoidance and Firm Value. Lindquist College of Business , University of Oregon Eugene, or 97403, USA

14. Desai, M.A (2012). A Better Way to Tax U.S Businesses. Harvard Business Review. https;// hbr.org/2012/07/abetter-way-o_tax_us_businesses

15. Dhaliwal, D., Gleason, C., \& Mills, L. M. (2004). Last-chance earnings management: Using the tax expense to meet analysts' forecasts. Contemporary Accounting Research, 21 (2), 431459.

16. Donohoe, M. P (2011). Financial derivatives in corporate tax avoidance, Why, How, and who? https//www. Researchgate.net/ publication/256012538. Di.10.2134/ssrn.1985763.

17. Dunbar, A, Higgens, D. M, Philips, J. D \& Plesko, G. A (2010) .What Do Measures of Tax Aggressiveness Measure? https://www.ntanet.org/wp_content/uploads/proce edings/200/003.
18. Essien, E. A., (2002) .Nigeria's Economic Growth: Performance and Determinant, CBN Economic and Financial Review, 40. (3).

19. Fuest, C.; Spengel, C.; Finke, K.; Heckemeyer, J. H.; Nuel P. A. (2013): Profit shifting and 'aggressive' tax planning by multinational firms: Issues and options for reform, ZEW Discussion Papers, No. 13-078.

20. Fukofuka, P (2013). The Contextual Framework of Corporate Income Tax Evasion. Journal of Accounting and Taxation. https://doi.org/10.5897/ JAT.vol.5 (2). Pp.27-37

21. Guenther, D. A., Matsunaga, S. R. \& Williams, B. M. (2013). Tax Avoidance, Tax Aggressiveness, Tax Risk and Firm Risk. Lundquist College of Business, University of Oregon, Eugene, OR 97403 USA.

22. Hanlon, M., \& Slemrod, J. (2009). What does tax aggressiveness signal? Evidence from stock price reactions to news about tax shelter involvement. Journal of Public Economics, 93, 126-141. http://dx.doi.org/10.1016/j.jpubeco.2008.09.004

23. Hanlon, M., \& Heitzman, S. (2010). A review of tax research. Journal of Accounting and Economics, 127-178. http://dx.doi.org/10.1016/j.jacceco.2010.09.002.

24. Heitzman, S. \& Michelle, H(2010). A Review of Tax Research. https://papers ssrn.com/5013/papers.cfm? id .1476561.138 pp.

25. Ifeuko, O. P, Morgui-Okawuru, P \& Anele, C. A (2008). A Performance Analysis of Nigerian Tax Objectives Actualization: Evidence of 2000-2012. An International Journal of Management Sciences and Business Administration. Vol.1. issue. Pp88100 url; doi.org/10.18375/ijmsba.1849-5664-41976-1008

26. Joe-Veer, T (2013).For Privileged Corporations: Paying State Taxes is increasingly becoming a thing of the Past. https;//www.joethetaxguy.co/2013/11

27. Jon N. K. (2012).The Real Effects of Opacity: Evidence from Tax Avoidance. Current Version: November 2012.

28. Kao. H, Wei, T (2014). The Effect OF IFRS, Information Asymmetry and Corporate Governance on U.S Operating of Accounting Information. https://ideas.repec,org/a/asai/aeafrj/ 2014.pp226-256.html. 
29. Khan. M, Srinivasan, S \& Tan, L (2017). Institutional Ownership and Corporate Tax Avoidance New Evidence. American Accounting Association (AAA). The accounting review, volume 92(2). https//doi.org/10.2318/accr-51529.

30. Kourdoumpalou. S. (2016). Do Corporate Governance Best Practices Restrain Tax Evasion? Evidence from Greece. Journal of Accounting and Taxation. https://doi.org/10.5897/JAT .0203. vol. 8 (1).pp.1-10.

31. Koumanakos, E., Roumelis, $\mathrm{T} \&$ Goletsis, $\mathrm{Y}$ (2017). Corporate Tax Compliance During MacroEconomic Fluctuations. Journal of Accounting and Taxation. https://doi.org/10.5897/JAT .0257. vol.9 (4) pp.36-55.

32. Leory, A \& Babra, B (2008). Tax and Economic Growth, Journal of Organization for Economic Co-operation and Development. ECO/WKP (2008)28 Available on the OECD internet website at www.oecd.org/eco/writing -papers.

33. Leuz, P \& Rebbeca, H. (2003). The Effect of Regulation (including taxation)on Financial Reporting and Disclosures. Journal of Accounting Research vol.41. issue 2 pp163444.https://onlinelibrary.wiley.com/toc/1475679x/ $41 / 2$

34. Lisa, J ,De-Simone, J and Jeri, K (2017).Does a Common Set of Accounting Standards Affect Tax -Motivated Income Shifting for Multinational Firms/ Journal of Accounting and Economics. February. 2017. Vol, 61. Issue 1 pp 145-165 https://www.gsb.stanford.edu/facultyresearch/family/lisa-de-semone.2007-2016

35. Lise, M. B \& Roberto, C. k (2015).Effects of the Convergence to International Financial Reporting Standards in Earnings Management. An International Journal of Finance and Accounting. ISSN 2168-4812 vol.4 (1) pp 8-20. Doi.10.5923/j.ijfa.401,02

36. Maydew, E. L , Dyreny, S. D \& Halon, (1997). The Effects of Executives on Corporate Tax Avoidance. The Accounting Review, vol.85 (4) pp1163-1189.

https://scholar.google.com/citations.user.

37. Maydew, E. L (2001). Empirical Tax Research in Accounting: A Discussion Journal of Accounting and

Economics.www.elsevier.com/locate/econbase.

38. Mills, L. F\& News berry, K. J (2001). The Influence of Tax and Non-Tax Costs on Book-Tax
Reporting Difference: public and private firms. The Journal of American Taxation Association: spring 2001, vol.23 No.1 pp.1-19

39. Oboh, P. K, Yeye, W \& Isa, V (2003).Treating the Interface between Engineering and Management. The International Journal of Production Economics.https://www.journal.elsevier.com/inter national-journal-of -production-economics. ISSN:0925-5273(-)

40. Oduro, R, Asiedu, M. A \& Tackie, G (2018). Determinants of Tax Evasion in the Developing Economies: A Structural Equation Model Approach of the Case of Ghana. Journal of Accounting and Taxation. https://doi.org/10.5897. JAT.0275. vol.10 (4). Pp37-47.

41. Omotoso, M. O. (2001). Principles of taxation. Ist Ed. Ibadan. First Shepherd investment.

42. Razak, A. A, \& Adafula, C.J (2013). Evaluating Tax Payer's Attitude and Its Influence on Tax Compliance Decision in Tamale, Ghana. Journal of Accounting and Taxation. https://doi.org/10.5897/JAT. vol.5 (3.pp.48-57

43. Saratu, P (2015).The Effect of Tax Avoidance on Government Budget Implementation in Southwest Nigeria. An International Journal of Accounting and Taxation. 4(1) pp 53-68. ISSN:2372-4986 (online) URL:https;//doi.org/10.15640/ijat.v4ala3

44. Towery, E. M. (2012). How do disclosures of tax aggressiveness to tax authorities affect reporting decisions? Evidence from Schedule UTP. The University of Texas at Austin Red McCombs School of Business.

45. Watson, L. (2015). Corporate Social Responsibility: Tax Avoidance, Earnings \& Performance. The Journal of the American Taxation Association: fall 2015, vol37,No2 pp121. https://doi.org/10.2308/ATAX- 51022.

46. Wegener, M. \& Labelle, R (2017).Is Business Ethics the, the Last Rampart" Against Tax Aggressiveness? International Journal of Accounting Research. Doi.10.4172/247244x.1000153. https:www.omicsonline.org/open access/.

47. Vythelinqum, P, Soondram, H \& Jugurnath, B. (2017).An Assessment of Tax Moral Among, Mauritius Taxpayers.. Journal of Accounting and Taxation. https://doi.org/10.5897/Jat .0224 . vol.9(1), PP.1-10. 